\title{
Investigation Some Quality Parameters of Sour Cherry Concentrates by Produced under Atmospheric and Vacuum Conditions
}

\author{
Filiz UCAN TURKMEN*1, Hatice Aysun MERCIMEK TAKCI², Büşra SEYHAN ${ }^{3}$, Tuba PALTA ${ }^{4}$ \\ ${ }^{* 1,3,4}$ Kilis 7 Aralık University, Faculty of Engineering and Architecture, Food Engineering Department, Kilis, Turkey \\ ${ }^{2}$ Kilis 7 Aralık University, Faculty of Science and Literature, Molecular Biology and Genetics Department, Kilis, Turkey
}

*Corresponding Author: ucanfiliz@gmail.com

Received: 15.11 .2018

Accepted: 30.06 .2019

\begin{abstract}
The some quality parameters of sour cherry concentrates by produced under atmospheric and vacuum conditions were investigated in this study. From these parameters, titration acidity, total soluble solids, total flavonoids and invert sugar values were statistically insignificant. But the remaining values were significant. Total phenolic contents of sour cherry juice samples increased to 194.50 and $112.00 \%$ after atmospheric and vacuum condition treatments. Total flavonoid values of samples ranged from 27.13 and $31.52 \mathrm{mg} / \mathrm{L}$. After atmospheric condition treatment, the ascorbic acid contents increased to $73.80 \%$ compared to control samples. The antioxidant activity (\% inhibition) ranged from 73.50 to $80.91 \%$. Total monomeric anthocyanin content $(22.71 \mathrm{mg} / \mathrm{L})$ at the begining increased to 60.76 and $98.54 \%$ after both applications. In total pectin values increased 181.88 and $90.38 \%$ after atmospheric condition and vacuum treatments.
\end{abstract}

Keywords: sour cherry, total phenolics, antioxidants, ascorbic acid, anthocyanin

\section{Açık Kazanda ve Vakum Altında Üretilen Vişne Ekşilerinin Bazı Kalite Parametrelerinin Araştırılması}

\section{$\ddot{\mathbf{O z}}$}

$\mathrm{Bu}$ çalışmada açık kazanda ve vakum altında üretilen vişne ekşilerinin bazı kalite parametreleri araştırılmıştır. Bu parametrelerden titrasyon asitliği, toplam çözülebilir katılar, toplam flavonoidler ve invert şeker değerleri istatistiksel olarak önemsiz bulunmuştur. Fakat geriye kalan değerler önemli bulunmuştur. Vişne suyu örneklerinin toplam fenolik içerikleri açık kazan ve vakum altındaki uygulamalarından sonra $\% 194.50$ ve $\% 112.00$ olarak artmıştır. Örneklerin toplam flavonoid değerleri 27.13 ile $31.52 \mathrm{mg} / \mathrm{L}$ arasında değişmiştir. Vakum altındaki uygulamadan sonra askorbik asit içerikleri control örnekleri ile karşılaştırıldığında \%73.80 artmıştır. Antioksidan aktivite (\% İnhibisyon) \%73.50 ile 80.91 arasında değişmiş̧ir. Başlangıçtaki toplam monomeric antosiyanin içeriği $(22.71 \mathrm{mg} / \mathrm{L})$ her iki uygulamadan sonar \%60.76 ile \%98.54'e artmıştır. Açık kazan ve vakum altındaki uygulamalardan sonar toplam pectin içeriği \%181.88 ve 90.38'e artmıştır.

Anahtar Kelimeler: Vişne, toplam fenolik, antioksidan, askorbik asit, antosiyanin. 


\section{Introduction}

Sour cherries (Prunus cerasus L.) are potentially raw material for functional foods because of substantial content of polyphenols, especially anthocyanins. Researchers have identified anthocyanins as anti-infl ammatory and anticarcinogenic agents, which are major contributors to the antioxidant activity in sour cherries (Repajic et al., 2015; Nowicka et al., 2015).

Sour-cherry juices are extensively used in the food industry. These products use as the constituents of juices, jellies, marmalades, jams, wine, beverages, etc. Sour-cherry juice as a drink is preferred to other fruit juices by the various customers It is a very popular product due to sweet-sour flavor (Belibağli and Dalgic, 2007; Cao et al., 2015).

In the fruit juice industry, they are processed to purees, concentrates and juices. Purees are used in the pastries, confectionary or dairy industry; juices or concentrates serve as source for fruit nectars and beverages (Bonerz et al., 2007). Additionally, sour cherries are a rich sourceof polyphenolsphytocomponents characterized by the presence of more than one phenol group in the molecule (Kolodziejczyk et al., 2013). Phenolics, especially anthocyanins, of sour cherries have been reported to possess anti-neurodegenerative, anti-inflammatory and anti-oxidative activities (Navruz et al., 2016). Because of their possible health benefits, a growing interest is being observed in the impact of processing on the antioxidant properties of these compounds (Wojdylo et al., 2014). Cherry fruits have a big potential as tasteful, harmless and healthy antimicrobial agents (Tamara et al., 2016).

However, sour cherry juice has a limited shelf life due to microbial spoilage and enzymatic activities. Thus, thermal treatment is applied to inactivate microorganisms and enzymes during juice production (Altuntas et al., 2010).

The harvested fruit is processed to fruit juice, jam and canned fruit because of the short time of harvesting period. Fruit juices were generally concentrated for: prolong their shelf life, decrease of the volume and transport, storage and packaging costs. However, the atmospheric treatments cause unwanted components and loss in quality features. The vacuum evaporation process is used as the most common concentration method (Sabancı and İçier, 2017).

In light of these informations, this present study is aimed to determine some quality parameters of sour cherry concentrates, produced under atmospheric and vacuum conditions. In our study, the concentrates produced from two different application were compared with regard to the physicochemical properties, color paramaters, bioactive compounds and antimicrobial activities. 


\section{Materials and Methods}

\subsection{Preparation of sour cherry juice samples}

The purchased sour cherries (from fruit bazaar in Kilis, Turkey) were washed by tap water to remove dirts after bringing to the our laboratory. Sour cherries were crushed by using a waring blender (Waring Laboratory Science, Torrington, USA) and filtering with a soft muslin cloth then poured to sterile glass brown bottles. The sour cherry juices were concentrated using a rotary vacuum evaporator (Buchi interface rotavapor, R-300, Swiss) and a atmospheric conditions under vacuum at $60^{\circ} \mathrm{C}$ until they reached about $68^{\circ}$ brix. Samples of concentrate sour cherry juice were stored at room temparature in brown bottles. All treatments and analysis were carried out in triplicates. Concentrates obtained from sour cherries (diluted to $15.5^{\circ}$ brix for analyses) were tested to the following analyses:

2.2. Physicochemical Analysis (Total soluble solids, pH, titratable acidity, water activity, viscosity, moisture and ash)

The $\mathrm{pH}$ and TSS analyses were made by WTW pH-meter (Weilheim, Germany) and Abbe refractometer (J.P. Selecta, WYA-25 model, Spain), respectively. Titratable acidity was made by an end point titration at $\mathrm{pH} 8.1$ with $0.1 \mathrm{~N} \mathrm{NaOH}$. The results calculated as citric acid were expressed as g/100mL (Sànchez-Moreno et al. 2003). By using a water activity meter (Novasina Labmaster Water Activity Meter, Switzerland) and a Fungilab Expert viscometer (Model L, Sant Feliu de Llobregat, Barcelona) were measured the water activity and viscosity values, respectively. The viscosity measures were made at $100 \mathrm{rpm}$ with spindle TL5 and TL7 and the results were expressed as cP.

For moisture content analysis, the $2 \mathrm{~g}$ example in the drying vessel, is based on the principle that the sample is held at $65^{\circ} \mathrm{C}$ under vacuum condition at 10 bar until constant weighing $(0.000$ grams) is reached. At the end of this period, the sample containers were weighed to the room temperature in a desiccator. The amount of dry matter in the samples was calculated as $\%$ according to the following formula: (AOAC, 2000).

$$
\text { moisture } \%=\frac{\left(\begin{array}{ll}
G-\mathrm{G} \\
\mathrm{G}
\end{array}\right) * 100}{\mathrm{G}_{2}-\mathrm{G}_{1}}
$$

In percentage ash analysis, to remove carbon, about $2 \mathrm{~g}$ of each sample, in a porcelain container, was ignited and incinerated in the ash furnace at about $550^{\circ} \mathrm{C}$ for $8 \mathrm{~h}$. The total ash was expressed as percent of dry basis: \%Ash=(Weight of residue/Sample Weight)*100 (AACC, 1999). 


\subsection{Determination of browning index}

In teflon tubes, $5 \mathrm{~mL}$ of sour cherry samples and $5 \mathrm{~mL}$ ethyl alcohol $(95 \%)$ were stirred and then centrifuged $\left(4000 \mathrm{rpm}, 10 \mathrm{~min}\right.$, at $\left.4^{\circ} \mathrm{C}\right)$. After then, the supernatant was passed through by using a $0.45 \mu \mathrm{m}$ teflon membrane filter. The absorbance of this supernatant was mesaured at $420 \mathrm{~nm}$ in a spectrophotometer (Biochrom, Libra S60, B, England) (Meydav et al., 1977).

\subsection{Color measurement}

Color (CIE L*, $\left.a^{*}, b^{*}\right)$ measurement was performed by the HunterLab Spectrofotometer (HunterLab miniscan EZ, USA). Approximate $50 \mathrm{~mL}$ of sour cherry samples were transferred into $20 \mathrm{~mm}$ Glass Optical Cell Light Path. According to the CIELAB color system, it was obtained the results. In present procedure, $\mathrm{L}^{*}$ describes lightness (0: black; 100: white), a* indicates the red/green value $((+)$ : red; $(-)$ : green $)$ and $b^{*}$ the yellow/blue value $((+)$ : yellow; $(-)$ : blue). The hue angle (o) shows a specific red, blue, yellow, or green color, or any combination of colors. Chroma indicates the intensity of a color. Also, the below formulas were utilized for the calculations of Hue*, $\mathrm{C}^{*}$ :

$$
\begin{aligned}
& \text { Hue }^{*}=\arctan \left(\frac{b^{*}}{a^{*}}\right) \\
& C^{*}=\sqrt{\left(a^{*}\right)^{2}+\left(b^{*}\right)^{2}}
\end{aligned}
$$

\subsection{Determination of HMF content}

The 5-hydroxymethylfurfural (HMF) content was quantitatively determined following the procedure described by Cemeroglu (2017) based on the colorimetric reaction between barbituric acid, p-toluidine and HMF, forming a red colour complex.

\subsection{Total phenolic contents}

Total phenolic contents were determined using spectrophotometric method. A standard curve was obtained according to the standard gallic acid solution in different concentrations. For this, 0.5 $\mathrm{mL}$ of the samples, $2.5 \mathrm{~mL}$ of $10 \%$ Folin-Ciocalteu's reagent and $2.5 \mathrm{~mL} \mathrm{7.5 \%} \mathrm{NaHCO}_{3}$ were added, respectively. Incubation of the reaction mixture was carried out in a water bath at $45^{\circ} \mathrm{C}$ for $45 \mathrm{~min}$. After, gallic acid equivalent was calculated in samples based on the absorbances measured at $765 \mathrm{~nm}$ (Biochrom, Libra S60, B, England) (Stankovic, 2011). 


\subsection{Total flavonoid contents}

The present analyis was carried out by the aluminium chloride colorimetric method (catechol as a standard). Initially, $1 \mathrm{ml}$ of sample was diluted (1:6), then mixed with $0.3 \mathrm{ml} \% 5 \mathrm{NaNO}_{2}$, incubated for $5 \mathrm{~min}$. Subsequently, $0.6 \mathrm{~mL}$ of $10 \% \mathrm{AlCl}_{3} .6 \mathrm{H}_{2} \mathrm{O}$ solution was added to the samples and incubated ( $5 \mathrm{~min}$ ), the mixture by adding $2 \mathrm{~mL}$ of $1 \mathrm{M} \mathrm{NaOH}$ solution was completed to $10 \mathrm{~mL}$ with double-distilled water. After 15 min incubation, the absorbance measures was made by UV-VIS spectrofotometer at $510 \mathrm{~nm}$ (Biochrom, Libra S60, B, England). The results of total flavonoid content were calculated as mg/L catechol (Sharm and Vig, 2013).

\subsection{DPPH Radical Scavenging Activity}

The antioxidant capacities of the all samples was determined by the stable DPPH (2,2-diphenyl 1-picrylhydrazyl) radical scavenging assay. In brief, $3.9 \mathrm{~mL}$ of the DPPH $(0.025 \mathrm{~g} / \mathrm{L}$ in methanol) solution was added to $100 \mu \mathrm{L}$ of the samples and the mixture was stirred with the vortex. Afterwars, the incubation was made in dark at room temperature for $120 \mathrm{~min}$. The remaining DPPH amount was determined by measuring at $515 \mathrm{~nm}$ absorbance. The inhibition of DPPH was assessed as percent according to the formula $\mathrm{I} \%=[($ Ablank-Asample) $/$ Ablank $] \times 100$ (Huang et al., 2005; Y1lmaz, 2011).

\subsection{Ascorbic acid content}

According to Hış1 (2004), the ascorbic acid content was carried out using 2,6-diclorophenolindophenol as color reagent at $518 \mathrm{~nm}$. The ascorbic acid contents was determined using the standard curve prepared with L-ascorbic acid.

\subsection{Invert sugar content}

$1 \mathrm{~mL}$ DNS reagent (3,5-dinitrosalicylic $10.6 \mathrm{~g}$, NaOH $19.8 \mathrm{~g}$ for $1416 \mathrm{~mL}$ distilled water) was added to $0.5 \mathrm{~mL}$ of the samples. The mixture was incubated to boil at $90^{\circ} \mathrm{C}$ for $5 \mathrm{~min}$. The reaction was stopped by adding $1 \mathrm{~mL}$ of $1 \mathrm{M}$ Rochelle's (Seignette) salt. Furtermore, the mixture was diluted with adding $2 \mathrm{~mL}$ distilled water and then the absorbance of this mixture spectrophotometrically was measured at $595 \mathrm{~nm}$ by estimation of reducing sugars. In this analysis that glucose was used as standard reducing sugar, the results were calculated as $1 \mu \mathrm{mol}$ glucose that was released per min (Mercimek Takci and Ucan Turkmen, 2016). 


\subsection{Total Monomeric Anthocyanin Content}

The monomeric anthocyanin contents was detected using the $\mathrm{pH}$ differential method suggested by Giusti and Wrolstad (2001). For analyis, the examples was diluted in buffers at pH 1.0 and 4.5 and let to equilibrate for $30 \mathrm{~min}$. Later using a UV-Vis spectrophotometer (Biochrom, Libra S60, B, England) measured the absorbances at $527 \mathrm{~nm}$ and $700 \mathrm{~nm}$ for haze correction. Based on cyanidin 3glucoside with molecular weight of 449.2 and extinction coefficient of 26.900 was the calculations. (Gil et al., 2000).

\subsection{Polymeric color analysis (Anthocyanin Degradation)}

Percent polymeric color was determined using the method described by Giusti and Wrolstad (2005). Sour cherry samples were diluted with water in order to have an absorbance reading between 0.5 and 1.0 at $512 \mathrm{~nm}$ when evaluated by an UV-Vis spectrophotometer (Biochrom, Libra S60, B, England). For the purpose, $2.8 \mathrm{~mL}$ diluted sample (bisulfite bleached sample) was prepared by adding $0.2 \mathrm{~mL}$ of potassium metabisulfite and $2.8 \mathrm{~mL}$ diluted sample (nonbleached, control sample) was get as add $0.2 \mathrm{~mL}$ of distile water. For equilibrating the mixtures were incubated during $15 \mathrm{~min}$, but not more than $1 \mathrm{~h}$, this mixtures were valuated at $\lambda=700,527$, and $420 \mathrm{~nm}$. Color density was evaluated using the control sample according to the following formula:

Color density $=[($ A420 nm - A700 nm $)+($ A527 nm - A700 nm $)] \times$ dilution factor

Polymeric color was calculated using the bisulfite-bleached sample using the following formula:

Polymeric color $=[($ A420 nm - A700 nm $)+($ A527 nm - A700 nm $)] \times$ dilution factor

Percent polymeric color was assessed using the formula:

$\%$ Polymeric color $=($ polymeric color/color density $) \times 100($ Brownmiller et al., 2008).

\subsection{Total pectin content}

Total pectin contents in the samples were determined according to the method described by List et al. (1985). Standard graphics were prepared as 10, 20, 30, 40, 50, 60, and $70 \mu \mathrm{g} / \mathrm{mL}$ from galacturonic acid anhydride and results were explained as GA-AH mg/L.

\subsection{Determination of Antimicrobial Activity}

Antimicrobial activities of the sour cheery juice and concentrate samples on Escherichia coli, Staphylococcus aureus and Candida albicans were tested by Kirby Bauer disc diffusion method. Mueller Hinton Agar (MHA) medium for bacteria and Potato Dextrose Agar (PDA) medium for fungi were used. Following inoculation by spreading, the sterile antibiotic discs absorbed $50 \mu \mathrm{L}$ sour 
samples were transfered to the plates. MHA and PDA plates were incubated at $37^{\circ} \mathrm{C}$ and $25-28^{\circ} \mathrm{C}$ for 24-48 hours. Antibiotic Vancomycin (HIMEDIA, $5 \mathrm{mcg} / \mathrm{disc}$ ) and Amphotericin B (HIMEDIA, 20 $\mathrm{mcg} / \mathrm{disc})$ were used as positive control. Thereafter, the inhibition zones around the discs were measured and calculated in $\mathrm{mm}$.

\subsection{Statistical analysis}

For analyses of variance (ANOVA) and Duncan's multiple comparison tests were preferred the software SPSS 21.0 for Windows (SPSS Inc., Chicago, IL, USA). All analysis were repeated at least three times.

\section{Results and Discussion}

\subsection{Physicochemical analyzes}

The results of the physicochemical analysis are depicted in Table 1. After concentration $\mathrm{pH}$ values of sour cherry juice were determined between 3.22 and 3.30, respectively in atmospheric condition and vacuum condition $(\mathrm{p}<0.05)$. These values for sour cherry juice samples indicated were at high acidity because of $\mathrm{pH}$ values between 3.22 and 3.30. TSS values of samples were detected as 15.53 and 15.47 after concentration, respectively ( $\mathrm{p}>0.05$ ). In sour cherry juice samples, TTA values ranged from 1.63 to $1.72 \mathrm{~g} / 100 \mathrm{~mL}(\mathrm{p}>0.05)$. $\mathrm{pH}$ values generally declined during treatments.

Table 1. Physicochemical analysis results of sour cherry juice samples

\begin{tabular}{c|c|c|c|c|c|c}
\hline & $\mathbf{p H}$ & $\begin{array}{c}\text { Total Soluble } \\
\text { Solid ('Brix) }\end{array}$ & $\begin{array}{c}\text { Titratable } \\
\text { Acidity (g/100 } \\
\mathbf{m L}\end{array}$ & $\begin{array}{c}\text { Water } \\
\text { Activity } \\
\left(\mathbf{a}_{\mathbf{w}}\right)\end{array}$ & $\begin{array}{c}\text { Moisture } \\
\mathbf{( \% )}\end{array}$ & $\begin{array}{c}\text { Ash } \\
\mathbf{( \% )}\end{array}$ \\
\hline $\begin{array}{c}\text { Control } \\
\text { Condmeric } \\
\text { Condition }\end{array}$ & $3.28 \pm 0.02^{\mathrm{a}}$ & $15.37 \pm 0.15^{\mathrm{a}}$ & $1.72 \pm 0.05^{\mathrm{a}}$ & $0.981 \pm 0.00^{\mathrm{a}}$ & $86.43 \pm 0.44^{\mathrm{a}}$ & $4.24 \pm 0.08^{\mathrm{b}}$ \\
\hline $\begin{array}{c}\text { Vacuum } \\
\text { Condition }\end{array}$ & $3.30 \pm 0.00^{\mathrm{a}}$ & $15.47 \pm 0.15^{\mathrm{a}}$ & $1.70 \pm 0.10^{\mathrm{a}}$ & $0.979 \pm 0.00^{\mathrm{a}}$ & $24.80 \pm 0.07^{\mathrm{b}}$ & $5.91 \pm 0.90^{\mathrm{a}}$ \\
\hline
\end{tabular}

Values followed by different superscripted letter within the same column are significantly different from each other $(\mathrm{p}<0.05)$.

Because of total soluble solids content, the titratable acidity rised to about $68 \%$. Damar and Ekşi (2012) reported that total acidity ranged from 16.4 to $26.3 \mathrm{~g} / \mathrm{L}$. This literature results were in accordance with our values. Bozdogan (2017) observed that the values of $\mathrm{pH}$, titrable acidity, TSS and ash in cornelian cherry concentrate were $2.09,2.1 \mathrm{~g} / 100 \mathrm{~mL}, 44.2^{\circ}$ Brix and $2.27 \%$, respectively. Sanchez (et al. 2015) reported that $\mathrm{pH}$ and TSS values in fresh cherry juice and juice concentrate 
were $3.71,3.90,18.7$ and $61^{\circ}$ Brix, respectively. These results based to minimal changes on $\mathrm{pH}$ and TSS are supported by the observation of Sanchez et al. (2015). Yalçınöz and Erçelebi (2015), reported that values of $\mathrm{pH}$, TSS and TTA in cornelian cherry concentrate were $2.90,43.52 \circ$ Brix and $1.49(\%$ citric acid), respectively.

Water activity values were determined to decrease 0.978 and $0.979(p>0.05)$ after concentration. Water activity is the availability of free water in a food product. Higher water activity indicates more biochemical or microbiological reactions and shorter storage stability (Sarabandi et al., 2017). Uçan et al. (2015) reported that water activity values ranged from 0.73 to 0.76 by concentration treatments. Eyigün (2012) said that the water activity values in the pomegranate samples produced under vacuum and atmospheric condition were found between 0.71-0.72 and 0.690.72 , respectively. Sanchez et al. (2015) reported that values of water activity in fresh and $61^{\circ}$ Brix concentrate cherry juice samples were detected as 0.973 and $0.824\left(\mathrm{a}_{\mathrm{w}}\right)$, respectively. In similarly to our results, they expressed insignificantly deviation on water activity.

Moisture values of samples, which is an important property, after concentration were found to decrease 73.27 and $71.30 \%(p<0.05)$. Ash values of samples, is a measure of the total amount of minerals present within a food, after concentration were detected to increase 62.02 and $39.38 \%$ $(p<0.05)$. Bonerz et al. (2007) studied the analytical characterization the impact of ageing on anthocyanin composition and degradation in juices from five sour cherry cultivars. In these cultivars, they found that values of $\mathrm{pH}$, total acid concentration, TSS and ash were 3.05-3.28, 13.98-20.14 g/L, (as malic acid), 13.84- 17.18 Brix and 4.90-7.17 g/L, respectively.

Viscosity analyzes were carried out in the highest speed that can be measured. In sour cherry juice sample, viscosity value was detected as $2.6 \mathrm{cP}$ (100 rpm, TL5 spindel). In atmospheric condition sample, viscosity value was determined as $28971 \mathrm{cP}$ (1,5 rpm, TL7 spindel). Under vacuum condition, it was found as $9479 \mathrm{cP}$ (6 rpm, TL7 spindel). Due to the "swelling" of particles and the diffusion of water between the cellulose chains may be occurred the increases of viscosity values (Ucan Turkmen and Mercimek Takci, 2018).

Generally, the results of physicochemical analyzes have affected by some factors such as growing conditions, storage conditions, geographical origin, and fruit maturity. Also, the changes in physicochemical results proceeded from methodology.

3.2. Determination of browning index, color $\left(L^{*}, a^{*}, b^{*}\right.$, hue and chroma), HMF and invert sugar of sour cherry juice samples

Browning index values were determined between 22.97 and 28.07 (abs.) (see Table 2). In atmospheric and vacuum condition after concentrations, the values increased 13.49 and $22.20 \%$, 
respectively $(\mathrm{p}<0.05)$.

Table 2. Browning index, color ( $\mathrm{L}^{*}, \mathrm{a}^{*}, \mathrm{~b}^{*}$, hue ve kroma), HMF and invert sugar values of sour cherry juice samples

\begin{tabular}{c|l|l|l|l|l|l|l|l}
\hline Samples & $\begin{array}{l}\text { Browning } \\
\text { index } \\
(\mathbf{a b s})\end{array}$ & $\mathbf{L}^{*}$ & $\mathbf{a}^{*}$ & $\mathbf{b}^{*}$ & Hue & Kroma & $\begin{array}{l}\text { HMF } \\
(\mathbf{m g} / \mathbf{L})\end{array}$ & $\begin{array}{l}\text { Invert } \\
\text { Sugar } \\
(\boldsymbol{\mu m o} / \mathbf{m L})\end{array}$ \\
\hline Control & $22.97 \pm 0.40^{\mathrm{b}}$ & $6.64 \pm 0.30^{\mathrm{c}}$ & $25.85 \pm 0.47^{\mathrm{b}}$ & $8.30 \pm 0.22^{\mathrm{b}}$ & $17.81 \pm 0.21^{\mathrm{b}}$ & $27.15 \pm 0.51^{\mathrm{b}}$ & $64.47 \pm 1.08^{\mathrm{c}}$ & $66.13 \pm 1.44^{\mathrm{a}}$ \\
\hline $\begin{array}{c}\text { Atmospheric } \\
\text { Condition }\end{array}$ & $26.07 \pm 2.84^{\mathrm{ab}}$ & $10.16 \pm 0.24^{\mathrm{b}}$ & $29.83 \pm 0.22^{\mathrm{a}}$ & $11.42 \pm 0.08^{\mathrm{a}}$ & $20.95 \pm 0.17^{\mathrm{a}}$ & $31.94 \pm 0.22^{\mathrm{a}}$ & $71.98 \pm 1.27^{\mathrm{a}}$ & $70.66 \pm 9.51^{\mathrm{a}}$ \\
\hline $\begin{array}{c}\text { Vacuum } \\
\text { Condition }\end{array}$ & $28.07 \pm 0.59^{\mathrm{a}}$ & $11.92 \pm 0.26^{\mathrm{a}}$ & $25.85 \pm 0.47^{\mathrm{b}}$ & $8.30 \pm 0.22^{\mathrm{b}}$ & $17.81 \pm 0.21^{\mathrm{b}}$ & $27.15 \pm 0.51^{\mathrm{b}}$ & $68.15 \pm 0.41^{\mathrm{b}}$ & $70.66 \pm 9.51^{\mathrm{a}}$ \\
\hline
\end{tabular}

Values followed by different superscripted letter within the same column are significantly different from each other $(\mathrm{p}<0.05)$.

The browning index value is assosicated the dark-colored components formed by the heat-based processes applied to the product and the severity of these processes. The accumulation of these components in the nutrients is caused to the incerases of the absorptive light and the browning index value.

Color is an important organoleptic property in the determination of product quality, therefore minimizing the pigment losses during processing is of primary concern to the processor (Yalçınöz and Erçelebi, 2015). In addition to, it was observed the increases in color values and these values found to be statistically significant $(\mathrm{p}<0.05)$. $\mathrm{L}^{*}$ values increased 53.01 and $79.51 \%$, respectively. $\mathrm{a}^{*}$, $\mathrm{b}^{*}$, hue and chroma values were evaluated to increase $15.39,37.59,17.63$ and $26.89 \%$ in atmospheric condition, respectively. Yalçinöz and Erçelebi (2015) detected that $\mathrm{L}^{*}, \mathrm{a}^{*}$ and $\mathrm{b}^{*}$ values in cornelian cherry concentrate $(43.52 \circ$ Brix) were $0.98,4.17$ and 0.78 , respectively. Damar (2010) reported that $L^{*}, a^{*}$ and $b^{*}$ values in eleven sour cherry cultivars were 19.30-19.78, 1.56-3.33 and 0.29-0.92, respectively.

After both concentration treatments, HMF values of concentrate samples increased 11.65(atmospheric) and 5.70(vacuum)\%. The differences between HMF values were detected to be statistically significant $(\mathrm{p}<0.05)$. In compared to sour cherry concentrated samples produced under vacuum treatment, the higher HMF amount was determined in atmospheric condition sample, as a result of longer heat treatment. HMF formation varies food content, processing type and storage conditions. The increases in HMF values after concentration processing were in accordance with rises reported in the literature (Ucan et al., 2015; Eyigün, 2012; Akçalığlu, 2014).

Invert sugar values of samples ranged from 66.13 to $70.66 \mu \mathrm{mol} / \mathrm{mL}$ ( $\mathrm{p}>0.05$ ) in our study. Bonerz et al. (2007) reported that in five sour cherry cultivars, values of sugar free extract, glucose and fructose were 59.4 -74.3, 48.7-63.4 and 39.6-52.2 g/L, respectively. 


\subsection{Determination of total phenolics, total flavonodis, DPPH (inhibition\%), ascorbic acid,} total monomeric anthocyanin, anthocyanin degradation and total pectin content of sour cherry juice samples

Total phenolic contents of sour cherry juice samples after atmospheric and vacuum condition treatments increased 194.50 and $112.00 \%$, respectively $(\mathrm{p}<0.05)$ (Table 3$)$.

Total flavonoid values of samples ranged from 27.13 and $31.52 \mathrm{mg} / \mathrm{L}(\mathrm{p}>0.05)$ (Table 3$)$. Sanchez et al. (2015) said that total phenolic contents were detected as 159 and 459 (mg/100 g) in fresh juice and juice concentrate, respectively. Bozdogan (2017) reported that the total phenolic, flavonoid and antioxidant activity values were $578 \mathrm{mg} / \mathrm{L}, 89 \mathrm{mg} / \mathrm{L}$ and 95.19\%, respectively. Bonerz et al. (2007) reported that total phenolics were $2704-4998 \mathrm{mg} / \mathrm{L}$ in five sour cherry cultivars, pasteurized $85^{\circ} \mathrm{C}$. In addition to, researchers calculated that ascorbic and citric acid concentrations were between 43 $177 \mathrm{mg} / \mathrm{L}$ and $0.08-0.14 \mathrm{~g} / \mathrm{L}$, respectively. Ucan et al. (2016) reported that total phenolics were increased after pasteurization and concentration treatments in lemon juices. Rajauria et al. (2010) reported that polyphenolic compounds are damaged during different processing operations, especially thermal application because of their sensitive to heat. Following thermal treatment of plants, complex phenomena happen and new compounds form. Except thermal decomposition, the most important reactions are hydrolysis, oxidation, polymerization and interaction of components (Naderi et al., 2016).

Table 3. Total phenolics, total flavanoids, antioxidant activiy, ascorbic acid, total monomeric anthocyanin content, anthocyanin degradation and total pectin content values of cheery samples

\begin{tabular}{c|l|l|l|l|l|l|l}
\hline Samples & $\begin{array}{l}\text { Total } \\
\text { phenolics } \\
(\mathbf{m g} / \mathbf{L})\end{array}$ & $\begin{array}{l}\text { Total } \\
\text { flavonoids } \\
\mathbf{( m g / L )}\end{array}$ & $\begin{array}{l}\text { DPPH } \\
\text { Inhibition) }\end{array}$ & $\begin{array}{l}\text { Ascorbic } \\
\text { acid (mg/L) }\end{array}$ & $\begin{array}{l}\text { Total } \\
\text { monomeric } \\
\text { anthocyanin } \\
(\mathbf{m g} / \mathbf{L})\end{array}$ & $\begin{array}{l}\text { Anthocyanin } \\
\text { Degradation } \\
\mathbf{( \% )}\end{array}$ & $\begin{array}{l}\text { Total } \\
\text { content (mg/L) }\end{array}$ \\
\hline Control & $449.8 \pm 1.2^{\mathrm{c}}$ & $28.39 \pm 0.69^{\mathrm{a}}$ & $79.02 \pm 3.51^{\mathrm{ab}}$ & $57.50 \pm 2.46^{\mathrm{b}}$ & $22.71 \pm 1.97^{\mathrm{b}}$ & $33.09 \pm 0.40^{\mathrm{b}}$ & $204.94 \pm 25.06^{\mathrm{c}}$ \\
\hline $\begin{array}{c}\text { Atmospheric } \\
\text { Condition }\end{array}$ & $1324.7 \pm 3.7^{\mathrm{a}}$ & $31.52 \pm 3.84^{\mathrm{a}}$ & $80.91 \pm 0.79^{\mathrm{a}}$ & $99.94 \pm 8.19^{\mathrm{a}}$ & $36.51 \pm 7.57 \mathrm{a}^{\mathrm{b}}$ & $50.85 \pm 1.98^{\mathrm{a}}$ & $577.70 \pm 5.81^{\mathrm{a}}$ \\
\hline $\begin{array}{c}\text { Vacuum } \\
\text { Condition }\end{array}$ & $953.6 \pm 15.9^{\mathrm{b}}$ & $27.13 \pm 3.59^{\mathrm{a}}$ & $73.50 \pm 3.49^{\mathrm{b}}$ & $52.88 \pm 2.27^{\mathrm{b}}$ & $45.09 \pm 10.59^{\mathrm{a}}$ & $50.48 \pm 1.14^{\mathrm{a}}$ & $390.16 \pm 9.85^{\mathrm{b}}$ \\
\hline
\end{tabular}

Values followed by different superscripted letter within the same column are significantly different from each other $(\mathrm{p}<0.05)$.

Ascorbic acid contents ranged from 57.50 to $99.94 \mathrm{mg} / \mathrm{L}$ in sour cherry samples. In these values, the atmospheric treatment indicated to the increase $(73.80 \%)$ compare with control samples. Furthermore, the differences of between samples were detected to be statistically significant $(\mathrm{p}<0.05)$ (Table 3). Many natural antioxidants such as ascorbic acid, are comparatively undecided, can be essentially lost (Lee and Chen, 1998; Lee and Coates, 1999). Kaur and Kapoor (2001) said that ascorbic acid is the most important water-soluble antioxidant and it protects compounds in 
extracellular and intracellular spaces in most biological systems and reduces tocopherol radicals back to their active form at the cellular membranes.

The DPPH (\%inhibition) values ranged from 73.50 to $80.91 \%$ and the results were determined to be statistically significant ( $p<0.05$ ) (see Table 3). Polydera et al. (2004) asserted that activities of naturally occurring antioxidants can be increase with processing or storage. Nicoli et al., 1999 said that polyphenols can show higher radical scavenging activity at an secondary oxidation state than the entirely nonoxidized ones. Natural antioxidants are significantly decompose as a consequence of processing. Several researchers discussed that thermal treatments are the main reason for the depletion of natural antioxidants (Naderi et al., 2016).

Total monomeric anthocyanin contents ranged from 22.71 to $45.09 \mathrm{mg} / \mathrm{L}$ and the difference between the treatments was found to be statistically significant $(\mathrm{p}<0.05)$ (Table 3$)$. Total monomeric anthocyanin value of untreated sample was initially $22.71 \mathrm{mg} / \mathrm{L}$ but atmospheric condition and vacuum treatments were determined to the increases 60.76 and $98.54 \%$. Researchers reported that cherry juice (18.7॰Brix) was evaporated at 40॰65 C (obtainded 61॰Brix). Sanchez et al. (2015) reported that monomeric anthocyanins were determined as 23.5 and 86.2 (mg/100 g), respectively in fresh juice and juice concentrate. Yalçınöz et al. (2015), found that total monomeric anthocyanins, total phenolics, total antioxidant activity in cornelian cherry concentrate (43.52 Brix), were 207 $\mathrm{mg} / \mathrm{L}, 0.028 \mathrm{GAE}$ and 96\%, respectively. However, total anthocyanin content and the anthocyanin fractions differed according to the sour cherry variety. The findings on monomeric anthocyanins in literature emphasized to state a wide scala of values (Damar and Eksi, 2012). Sanchez et al. (2015) reported that anthocyanins under normal processing and storage at room temperature turn relatively easy into colourless compounds and subsequently to insoluble brown pigments. Cherry juice is a good source of anthocyanins, but theirs stability changes during heat processing or accelerated storage.

Anthocyanin degradation (percent polymeric color) values ranged from 33.09 to $50.85 \%$ (see Table 3). Damar (2010) reported that percent polymeric color ranged from 9.5 to $32.9 \%$ and in monomeric anthocyanin and percent polimeric color values showed to generally increase from pressed to evaporated. Sadilova et al. (2006) suggested that the degradation mechanism is due to hydrolysis of the anthocyanin sugar moiety which leads to formation of a phenolic non bioactive aglycone. Oliveira et al. (2010) suggested that anthocyanins are naturally unstable and degradation is primarily caused by oxidation.

Total pectin values of all samples ranged from 204.94 to $577.70 \mathrm{mg} / \mathrm{L}(\mathrm{p}<0.05)($ Table 3$)$. In addition to, after atmospheric condition and vacuum treatments, the values were reported to the incrase 181.88 and $90.38 \%$. Bonerz et al. (2007) reported that colloids were 1336- $2378 \mathrm{mg} / \mathrm{L}$. Uçan et al. (2014), found to determine the increase in total pectin content with pasteurization. 


\subsection{Microbial analysis of sour cherry juice samples}

Antimicrobial activity on test microorganisms are showed in Table 4.

Table 4. Antimicrobial activity results of sour cheery juice concentrate samples ( $\mathrm{mm})$

\begin{tabular}{c|c|c|c}
\hline Samples & E.coli & S. aureus & C. albicans \\
\hline Vancomycine & - & 12 & - \\
\hline Amphotericin B & - & - & - \\
\hline Control & 7 & 6 & - \\
\hline Atmospheric Condition & 14 & 16 & - \\
\hline Vacuum Condition & 17 & 15 & - \\
\hline
\end{tabular}

The sour cherry juice samples were effective against the tested bacteria. But none of samples were active on C. albicans. Atmospheric condition and vacuum condition samples are more active than standart antibiotic against E.coli and S.aureus (Figure 1-2). The highest antimicrobial activity with $17 \mathrm{~mm}$ inhibition zone, were recorded on E. coli in vacuum condition sample. The highest antimicrobial activity on $S$. aureus was detected in atmospheric condition (16 mm) (Figure 2).

In the concentrated sour cherry juices were observed to increase acidity (total acidity and ascorbic acid content) and total phenolic contents (antimicrobial agent). The tested bacteria are sensitive to the high acidity such as pH 3.22-3.30. So, the observed bacterial inhibition may be assosicated with acidity and phenolic contents in samples. Also, C.albicans is resistance to $\mathrm{pH}$ changes (especially acidity). Therefore, it may be explained to not observe the inhibition zone.

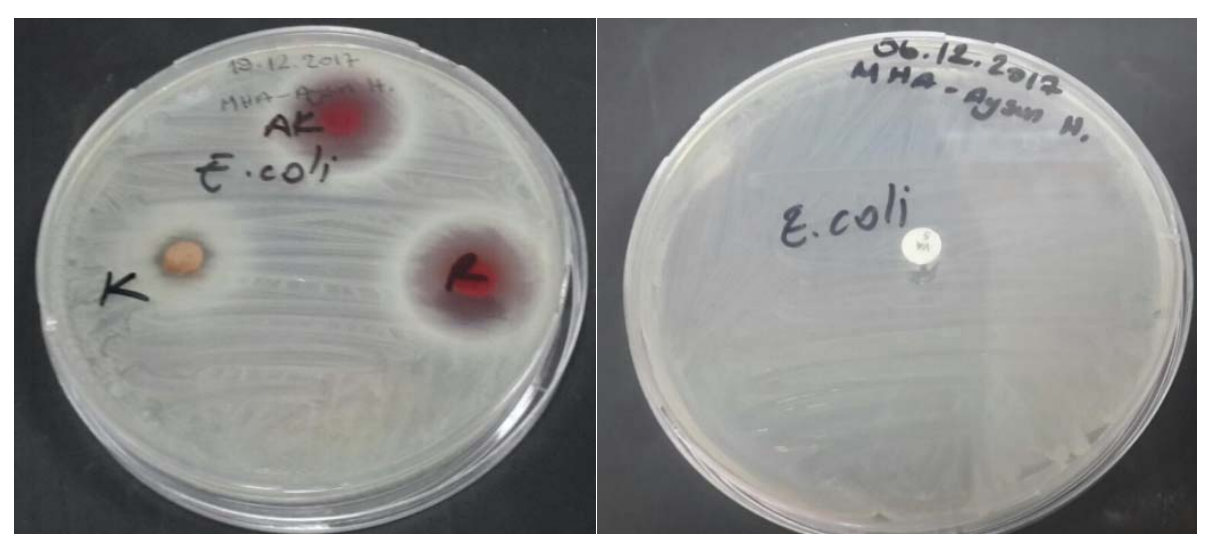

Figure 1. Antimicrobial effect of sour cherry juice samples against E.coli 


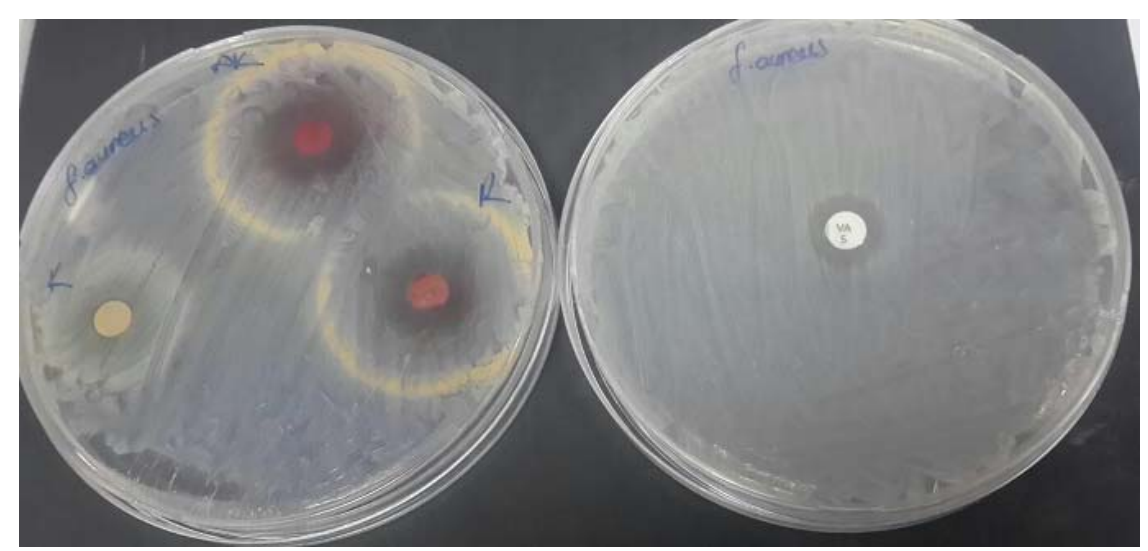

Figure 2. Antimicrobial effect of sour cherry juice samples against S.aureus

\section{Conclusion}

Results of this study revealed that sour cherry juice can be used as sour give taste and flavor to soups, salads and local foods such as pomegranate, koruk, plum, sumac, lemon and citrus sour. To endure last longer and conserve their freshness without deterioration, also the antimicrobial effects on food-borne pathogenic microorganisms may be suggested to use in Turkish cuisines. Besides traditional products produced by atmospheric condition, the concentrated sour obtained by vacuum condition is better quality product because of the high bioactive compounds and color quality. For this reason, the production at low temperatures under vacuum, give minor damage to the sour quality characteristics. The vacuum condition treatment may be proposed to the sour consumption for both of factory and traditional production. As the conventional food additives and flavorings, sour cherry concentrates may be used as natural food flavoring agents in the food industry products.

\section{Acknowledgements}

The chemical demands and equipments of this work were supplied from the Kilis 7 Aralık University. For this reason, we thank Kilis 7 Aralık University.

\section{References}

AACC International, (1999). Approved Methods of Analysis. Methods 08-01.01, 44- 19.01, 54-40.02 and 7631.01. Approved November 3, 1999, eleventh ed. AACC International, St. Paul, MN, USA.

Akçalıoğlu, O., Ağçam, E., Polat, S., Uçan, F., Aslan, S. and Akyıldız, A. (2014). Turunç ekşisi üzerine bir araştırma (A research on concentrated bitter orange juice). 4. Geleneksel Gidalar Sempozyumu, 1719 Nisan, 814-818.

Altuntas, J., Evrendilek, G. A., Sangun, M. K., \& Zhang, H. Q. (2010). Effects of pulsed electric field processing on the quality and microbial inactivation of sour cherry juice. International journal of food science \& technology, 45(5), 899-905.

AOAC., (2000). Official methods of analysis no 985.26 (17th edn), Washington, DC, Association of Official Analytical Chemists. 
Belibağli, K. B., \& Dalgic, A. C. (2007). Rheological properties of sour cherry juice and concentrate. International journal of food science \& technology, 42(6), 773-776.

Bhat. R. 2016. Food Chem. 213, 635-640

Bonerz, D., Würth, K., Dietrich, H., \& Will, F. (2007). Analytical characterization and the impact of ageing on anthocyanin composition and degradation in juices from five sour cherry cultivars. European Food Research and Technology, 224(3), 355-364.

Bozdogan, A. (2017). Viscosity and physicochemical properties of cornelian cherry (Cornus mas L.) concentrate. Journal of Food Measurement and Characterization, 11(3), 1326-1332.

Brownmiller, C., Howard, L. R., \& Prior, R. L. (2008). Processing and storage effects on monomeric anthocyanins, percent polymeric color, and antioxidant capacity of processed blueberry products. Journal of food science, 73(5).

Cao, J., Jiang, Q., Lin, J., Li, X., Sun, C., \& Chen, K. (2015). Physicochemical characterisation of four cherry species (Prunus spp.) grown in China. Food chemistry, 173, 855-863.

Cemeroğlu, B. (2007). Gıda Analizleri. Gıda Teknolojisi Derneği Yayınları: Ankara, No:34, 535p.

Damar, I.,, \& Ekşi, A. (2012). Antioxidant capacity and anthocyanin profile of sour cherry (Prunus cerasus L.) juice. Food chemistry, 135(4), 2910-2914.

Damar, İrem. (2010). Vişne suyunun antosiyanin profili ve antioksidan kapasitesi. Ankara Üniversitesi, Fen Bilimleri Enstitüsü Sayfa Sayıs1: 81.

Eyigün, F.Ş. (2012). Hicaz Nar Çeşidine Ait Narlardan Elde Edilen Nar Ekşilerinin Özelliklerinin Belirlenmesi Üzerine Bir Araştırma. Çukurova Üniversitesi, Fen Bilimleri Enstitüsü, Gıda Mühendisliği Anabilim Dalı, Yüksek Lisans Tezi, 112s.

Giusti, M.M., Wrolstad, R. E. (2001). Characterization and measurement with UV-visible spectroscopy. In Current Protocols in Food Analytical Chemistry. R. E. Wrolstad, S. J. Schwartz (Eds), John Wiley and Sons, New York, pp 1-13,.

Gil, M.I., Tomas-Barberan, F.A., Hess-Pierce, B., Holcroft, D.M., Kader, A. A. (2000). Antioxidant activity of pomegranate juice and its relationship with phenolic composition and processing. Journal of Agricultural and Food Chemistry, 48:4581-4589.

Giusti MM, Wrolstad RE. (2005). Unit F1.2: characterization and measurement of anthocyanins by UV-visible spectroscopy. In: Wrolstad RE, editor. Handbook of food analytical chemistry-pigments, colorants, flavors, texture, and bioactive food components. New York: JohnWiley \& Sons Inc. p F1.2.1-13.

Hışı1, Y. (2004). Enstrümental Gıda Analizleri-Laboratuvar Deneyleri. Ege Üniversitesi, Mühendislik Fakültesi, Ders Kitapları, Bornova, İzmir, Yayın no: 45, 39 s.

Huang, D., Ou, B. and Prior, R.L. (2005). The Chemistry Behind Antioxidant Capacity as Says. J. Agric. Food Res. 53: 1841-1856.

Kaur C, Kapoor HC. (2001). Antioxidants in fruits and vegetables-the millennium's health. Int J Food Sci Technol 36:703-725

Kołodziejczyk, K., Sójka, M., Abadias, M., Viñas, I., Guyot, S., \& Baron, A. (2013). Polyphenol composition, antioxidant capacity, and antimicrobial activity of the extracts obtained from industrial sour cherry pomace. Industrial crops and products, 51, 279-288.

Lee HS, Chen CS. (1998). Rates of vitamin C loss and discoloration in clear orange juice concentrate during storage at temperatures of 4-24 ${ }^{\circ} \mathrm{C}$. J Agric Food Chem 46:4723-4727.

Lee HS, Coates GA. (1999). Thermal pasteurization effects on color of red grapefruit juices. J Food Sci 64(4):663-666.

List, D. Buddruß, S. and Bodtke, M. (1985). "Pectinbestimmung mit meta-phenylphenol," Zeitschrift F"ur Lebensmittel-Untersuchung und Forschung, vol. 180, no. 1, pp. 48-52.

Mercimek Takc1, H. A., \& Ucan Türkmen, F. (2016). Extracellular pectinase production and purification from a newly isolated Bacillus subtilis strain. International journal of food properties, 19(11), 2443-2450.

Meydav, S., Saguy, I. and Kopelman, I. J. (1977). Browning determination in citrus products. J. Agric. and Food Chem. 25(3): 602-604.

Naderi, B., Maghsoudlou, Y., Aminifar, M., Ghorbani, M., \& Rashidi, L. (2016). Comparison of Microwave with Conventional Heating on Phytochemical Compounds of Cornelian Cherry (Cornus mas L.) Concentrate. Journal of Agricultural Science and Technology, 18(5), 1197-1208.

Navruz, A., Türkyılmaz, M., \& Özkan, M. (2016). Colour stabilities of sour cherry juice concentrates enhanced with gallic acid and various plant extracts during storage. Food chemistry, 197, 150-160.

Nicoli MC, Anese M, Parpinel M. (1999). Influence of processing on the antioxidant properties of fruit and vegetables. Trends Food Sci Technol 10:94-100 
Nowicka, P., Wojdyło, A., Lech, K., \& Figiel, A. (2015). Chemical composition, antioxidant capacity, and sensory quality of dried sour cherry fruits pre-dehydrated in fruit concentrates. Food and bioprocess technology, 8(10), 2076-2095.

Oliveira, C., Amaro, L. F., Pinho, O. And Ferreira, I. M. P. L. V. O. (2010). Cooked Blueberries: Anthocyanin and Anthocyanidin Degradation and Their Radical Scavenging Activity. J. Agri. Food. Chem., 58(6): 9006-9012.

Polydera AC, Stoforos NG, Taoukis PS (2004). The effect of storage on the antioxidant activity of reconstituted orange juice which had been pasteurized by high pressure or heat. Int J Food Sci Technol 39:783-791.

Rajauria, G., Jaiswal, A. K., Ghannam, N. A. and Gupta, S. (2010). Effect of Hydrothermal Processing on Colour, Antioxidant and Free Radical Scavenging Capacities of Edible Irish. Brown Seaweeds. Int. J. Food Sci. Technol., 45: 2485-2493.

Repajić, M., Kovačević, D. B., Putnik, P., Dragović-Uzelac, V., Kušt, J., Čošić, Z., \& Levaj, B. (2015). Influence of cultivar and industrial processing on polyphenols in concentrated sour cherry (Prunus cerasus L.) juice. Food technology and biotechnology, 53(2), 215.

Sabanci, S., \& Icier, F. (2017). Applicability of ohmic heating assisted vacuum evaporation for concentration of sour cherry juice. Journal of Food Engineering, 212, 262-270.

Sánchez Moreno, C., Plaza, L., De Ancos, B. and Cano, M. P. (2003). Quantitative bioactive compounds assessment and their relative contribution to the antioxidant capacity of commercial orange juices. J. Sci. Food and Agric, 83(5):430-439.

Sanchez, V., Baeza, R., \& Chirife, J. (2015). Comparison of monomeric anthocyanins and colour stability of fresh, concentrate and freeze-dried encapsulated cherry juice stored at $38 \mathrm{C}$. Journal of Berry Research, 5(4), 243-251.

Sadilova, E., Stintzing, F. C. and Carle, R. (2006). Thermal Degradation of Acylated and Nonacylated Anthocyanins. J. Food. Sci., 71(8): C504-C512.

Sarabandi, K., Peighambardoust, S. H., Mahoonak, A. S., \& Samaei, S. P. (2017). Effect of carrier types and compositions on the production yield, microstructure and physical characteristics of spray dried sour cherry juice concentrate. Journal of Food Measurement and Characterization, 11(4), 1602-1612.

Sharm, S. and Vig P. A. (2013). Evaluation of in Vitro Antioxidant Properties of Methanol and Aqueous Extracts of Parkinsoniaaculeata L. Leaves. The Scientific World Journal, 1-7.

Stankovic, M. S. (2011). Total phenolic content, flavonoid concentration and antioxidant activity of Marrubium peregrinum L. extracts. Kragujevac J. Sci. 33:63-72.

Tamara, K., Lj1jana, S., Srðan, S., Zagorka, C. L., Jadranka, D., Ivana, C., \& Stefanovic, V. (2016). Antimicrobial activity of sour cherry. Agro Food Industry Hi Tech, 27, 1.

Uçan, F., Akyıldız, A., Ağçam, E., \& Polat, S. (2015). Limon Ekşisi Üretimi Üzerine Bir Araştırma. GIDA, 39(5), 283-290.

Ucan Türkmen, F. \& Mercimek Takci, H. A. (2018).Ultraviolet-C and ultraviolet-B lights effect on black carrot (Daucus carota ssp. sativus) juice. Journal of Food Measurement and Characterization, 1-9.

Uçan, F., Ağçam, E., \& Akyildiz, A. (2016). Bioactive compounds and quality parameters of natural cloudy lemon juices. Journal of food science and technology, 53(3), 1465-1474.

Uçan, F., Akyildiz, A., \& A ğçam, E. (2014). Effects of different enzymes and concentrations in the production of clarified lemon juice. Journal of Food Processing, 2014.

Wojdyło, A., Figiel, A., Lech, K., Nowicka, P., \& Oszmiański, J. (2014). Effect of convective and vacuummicrowave drying on the bioactive compounds, color, and antioxidant capacity of sour cherries. Food and Bioprocess Technology, 7(3), 829-841.

Y1lmaz, O. M. (2011). Determination of The Antioxidant Activity and Phenolic Acid Composition of Main Wheat Varieties Grown in Turkey and Enrichment of Bread with Pomegranate Husk Extract. PhDThesis. Ankara University, pp 80.

Yalçinöz, Şelale Kara, and Emine Alben Erçelebi. (2015). Anthocyanin degradation and colour kinetics of cornelian cherry concentrate.: 1-12. 